\title{
Legemiddelassistert rehabilitering - viktig behandling med dilemmaer
}

\author{
Legemiddelassistert rehabilitering ved opioidavhengighet (LAR) ble introdusert i USA i 1960-årene. Behand- \\ lingen ble i Norge lenge avvist på prinsipielt grunnlag. Først i 1998 - etter sterk økning i overdosedødsfall \\ utover i 1990-årene - ble LAR-behandling innført som et landsdekkende program. Det er fremdeles omstridt, \\ og enkelte er kritiske til måten LAR drives på i Norge i dag. I denne kronikken vil vi, med bakgrunn i norsk \\ og internasjonal forskning, argumentere for at legemiddelassistert rehabilitering er viktig behandling samt \\ drøfte utfordringer og dilemmaer fagfeltet nå står overfor.
}

Ivar Skeie

ivar.skeie@gmail.com

Thomas Clausen

Anne Bukten

Opioidavhengighet er et stort globalt helseproblem, og dødeligheten blant opioidavhengige er meget høy. I en fersk metaanalyse ble dødsraten på verdensbasis beregnet til 2,1 \% per år, og den aldersjusterte dødeligheten er 15 ganger høyere enn for befolkningsgjennomsnittet (1). Sosiale problemer og kriminalitet, akutte og kroniske somatiske sykdommer og skader samt alvorlige og lettere psykiske lidelser forekommer også hyppig blant opioidavhengige.

\section{LAR - kurativ eller symptomatisk behandling?}

I vedlikeholdsbehandling erstattes illegal bruk av opioider med jevn tilførsel av et langtidsvirkende opioid i doser som verken gir rus eller abstinens. Opioidsuget fjernes eller reduseres - det muliggjør atferdsendring, stabilisering og sosial rehabilitering. Målet er altså ikke avvenning fra opioider, men stabilisering gjennom jevn tilførsel.

Ser man på opioidavhengighet som «sykdom» i denne sammenhengen, er behandlingen ikke kurativ fordi «sykdommen» (avhengigheten) ikke fjernes, men mye av skadevirkningene av den forsvinner. Slik sett er legemiddelassistert rehabilitering symptomatisk behandling som kan sammenliknes med stabiliserende medikamentell behandling for andre tilstander der det ikke finnes kurativ behandling, som f.eks. hiv/aids eller diabetes. Effekten må derfor først og fremst måles ved å sammenlikne pasientenes helsemessige og sosiale situasjon under behandling med deres tilstand utenfor LAR-programmet.

\section{Positive effekter}

Studier fra en rekke land har de siste tiårene vist at vedlikeholdsbehandling er assosiert med redusert rusmiddelbruk, lavere dødelighet og sykelighet og mindre kriminalitet.

\section{Dødelighet}

Dødeligheten blant opioidavhengige er høy og reduseres under behandling (1). I en studie ble dødeligheten under vedlikeholdsbehandling estimert til en firedel av hva den var i perioder uten behandling (2). I en norsk studie var dødeligheten i perioden 1997-2003 2,4\% per år på venteliste, sammenliknet med 1,4\% per år i LARbehandling.

Reduksjonen skyldtes en nedgang på $80 \%$ i dødelige overdoser (3). For personer under 35 år var risikoen for dødelige overdoser spesielt høy, og den ble halvert under LAR-behandling (4).

\section{Kriminalitet}

Studier fra flere land har vist redusert kriminalitet under vedlikeholdsbehandling $(5,6)$. I Norge hadde de som søkte LARbehandling i perioden 1997-2003 gjennomsnittlig mer enn seks domfellelser de siste tre årene før de søkte behandling (7). Nærmere $80 \%$ av disse skyldtes vinningsforbrytelser og narkotikalovbrudd.

Under LAR-behandling var antall domfellelser for vinningskriminalitet, narkotikalovbrudd, vold (8) og kjøring i beruset tilstand (9) betydelig redusert, og den samlede domfellelsesraten var mer enn $50 \%$ lavere enn før behandling.

\section{Sykelighet}

Reduksjon i somatisk sykelighet under LAR-behandling er dokumentert i studier basert på intervjuer, klinisk vurdering og liggetid i sykehus. I en fersk norsk studie ble forekomsten av akutte sykdomsepisoder som ble behandlet i sykehus de siste fem år før LAR-behandling sammenliknet med de fem første år i behandling i en gruppe på 200 LAR-pasienter (10).

Den samlede reduksjon i sykdomsepisoder under behandling var $37 \%$, og forekomsten av rusrelaterte episoder (overdoser/injiseringsrelaterte/andre) ble redusert med $76 \%$.

\section{Har alle LAR-pasienter nytte av behandlingen?}

Ikke alle blir rusfrie med LAR-behandling. I 2012 ble $49 \%$ vurdert å ha god rusmestring, det vil si at de ikke hadde rusmiddelbruk av vesentlig betydning for sosial funksjon eller livskvalitet (11). 15\% hadde en avhengighetspreget bruk som dominerte livsførselen, mens $23 \%$ var i en mellomkategori (13\% ukjent). Vi må ha som utgangspunkt at nær $100 \%$ hadde avhengighetspreget rusmiddelbruk før LARbehandlingen.

Enkelte hevder at LAR-pasienter som ikke oppnår rusfrihet, ikke har nytte av behandlingen og at den derfor for deres del bør avsluttes (12). En fersk norsk studie viste imidlertid at den firedelen av LARpasientene som brukte mest rusmidler, hadde en reduksjon på hele $72 \%$ i rusrelaterte sykdomsepisoder behandlet i sykehus sammenliknet med før de fikk legemiddelassistert rehabilitering (10).

Dette funnet samsvarer med en fersk studie fra sprøyteutdelingsprogrammet i Oslo, der LAR-pasienter som benyttet seg av programmet, hadde lavere forekomst av overdoser, heroinbruk, injisering og kriminalitet enn sprøytebrukere som ikke var under legemiddelassistert rehabilitering (13). Disse funnene underbygger antakelsen om at også LARpasienter med fortsatt risikopreget rusatferd til tross for dette har nytte av behandlingen fordi skadevirkningene av rusmiddelbruken blir betydelig mindre.

\section{Hva skjer etterpå?}

Et mindretall av pasientene som avslutter legemiddelassistert rehabilitering gjør dette etter planmessig nedtrapping og i stabil rusfrihet. De fleste avbryter behandlingen i en periode med pågående rusmiddelbruk og behandlingsproblemer (14). Vedlikeholdsbehandling fjerner ikke opioidavhengigheten. 


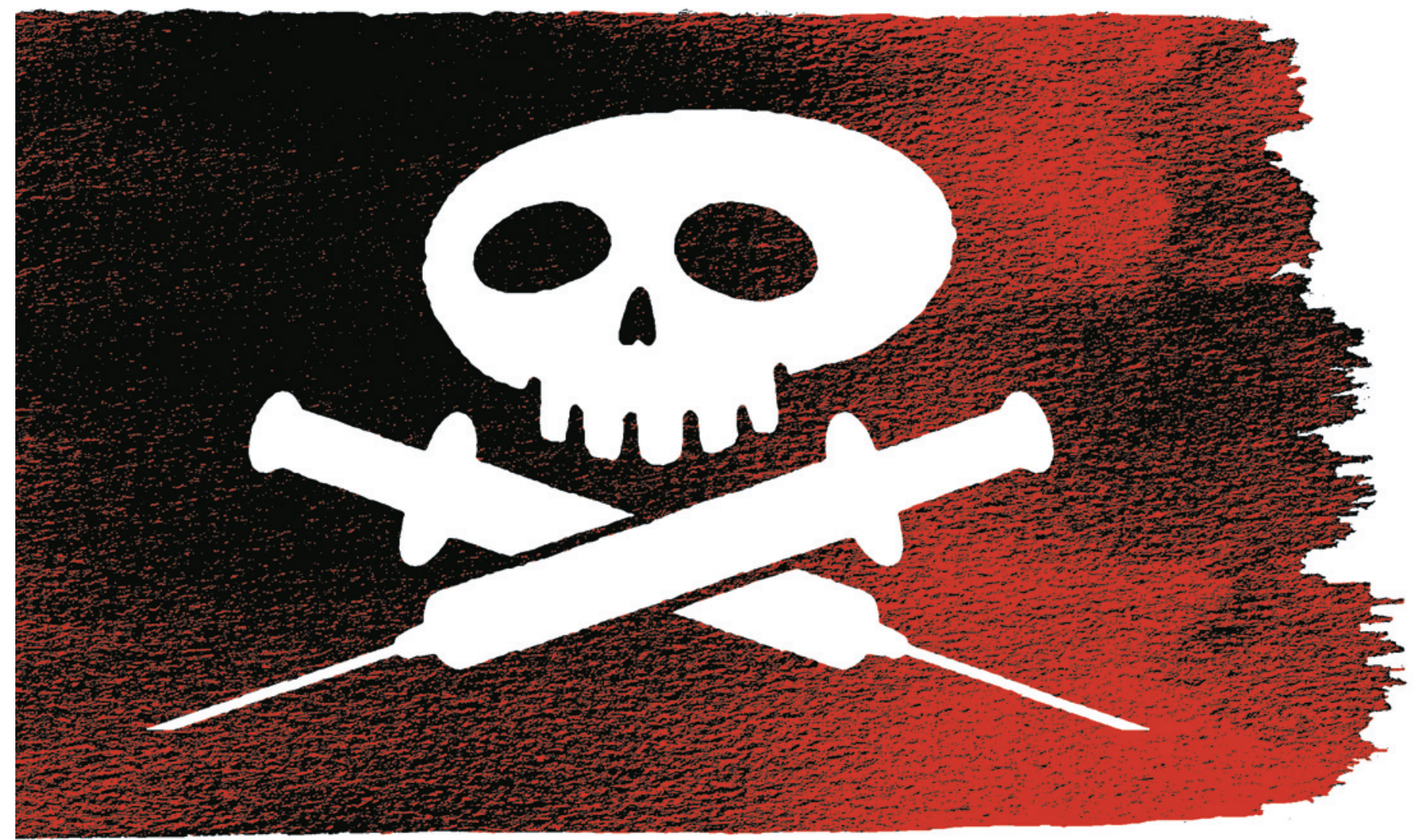

Illustrasjon @ Superpop

Flere studier viser at risikoen for tilbakefall etter behandlingsavbrudd er høy, både blant dem som er rusfrie ved behandlingsavslutning og spesielt blant dem som ikke er stabilisert før avbrudd i behandlingen $(15,16)$.

I et pasientmateriale fra Vest-Agder var det stor ustabilitet $\mathrm{i}$ behandlingsstatus i tiden etter legemiddelassistert rehabilitering, med en risiko for død på $4 \%$ per år (17). De fleste av dem som avsluttet behandlingen, var likevel tilbake i vedlikeholdsbehandling i løpet av de første par årene etter LAR-avbrudd. Det er også viktig å understreke at en liten gruppe (10\%) av dem som avsluttet, typisk etter langvarig rusfrihet med planlagt nedtrapping, lyktes i å leve et stabilt og langvarig rusfritt liv. Dette stemmer overens med funn fra Sverige (16).

\section{Å nå målgruppen og holde pasientene i behandling}

De positive effektene av vedlikeholdsbehandling er altså store, også for dem som ikke er stabilt rusfrie. Etter behandlingsavbrudd er risikoen for tilbakefall med overdoser og andre alvorlige komplikasjoner stor. Generelt bør det derfor være et mål å holde flest mulig i behandling. Graden av frafall er en viktig kvalitetsindikator for vedlikeholdsbehandling (6). I 2012 avsluttet 326 LAR-behandling (4,4\%), og 212 som tidligere hadde avsluttet, startet opp med behandling på ny (11). Frafallet fra vedlikeholdsbehandling i Norge er altså lavt.

Legemiddelassistert rehabilitering dekker i dag kanskje bare om lag 50\% av målgruppen på landsbasis (18). Et LAR-program som når ut til en større del av målgruppen og opprettholder dagens lave frafallsgrad, vil være et viktig tiltak for å redusere den høye overdosedødeligheten i Norge.

Stabilt rusfrie pasienter som vurderer å avslutte legemiddelassistert rehabilitering, bør informeres om risikoen for tilbakefall, men også om muligheten til å lykkes med å leve et rusfritt liv uten vedlikeholdsbehandling. Dersom de bestemmer seg for å avslutte behandlingen etter nedtrapping, bør behandlingsapparatet gi støtte og oppfølging under og etter denne perioden, og de bør tas raskt inn igjen dersom de skulle ønske det. Bruk av langtidsvirkende opioidblokade (naltrekson) kan være et hjelpemiddel til å forhindre opioidbruk etter nedtrapping.

\section{Utilsiktede negative effekter}

Lekkasje av LAR-medikamenter til det illegale markedet er alvorlig, fordi medikamentene, i særlig grad metadon, kan medføre overdosefare når de brukes av personer som ikke har tilsvarende opioidtoleranse som LAR-pasienter. I Norge ble det i peri- oden 2000-06 påvist 312 metadonrelaterte forgiftningsdødsfall, men bare $22 \%$ av de døde var under LAR-behandling ved det tidspunktet (19).

Dødsfall opptrer som regel ved samtidig bruk av andre rusmidler, som alkohol, benzodiazepiner og andre opioider. Det er derfor viktig at utleveringen, spesielt av metadon, organiseres slik at risikoen for lekkasje blir minst mulig.

I flere land registreres en økende andel av opioidavhengige som har hatt LARlegemidlene som innfallsport til avhengigheten. Dersom lekkede LAR-medikamenter i vesentlig grad bidrar til rekruttering av nye opioidavhengige også i Norge, gir dette grunn til bekymring.

\section{Konklusjon}

Vårt syn er at legemiddelassistert rehabilitering er god behandling. Mange oppnår gjennom LAR-behandling rusfrihet og sosial rehabilitering. Andre, som fortsetter å bruke rusmidler under behandlingen, har færre skadevirkninger av opioidavhengigheten. Ved rusing og behandlingsproblemer bør målet være å stabilisere pasienten og tilrettelegge og videreføre behandlingen.

Det er etter vårt syn ikke riktig å se på «skadereduksjon» og «rehabilitering» som motsetninger - de er likeverdige og ofte 
parallelle målsettinger i behandlingen, riktignok ofte med ulike tidsperspektiver. En av utfordringene fremover blir å videreutvikle LAR-programmet slik at en større del av målgruppen nås og beholdes $\mathrm{i}$ behandling.

\section{Ivar Skeie (f. 1952)}

er ph.d., spesialist i allmennmedisin, overlege i tverrfaglig spesialisert rusbehandling ved DPS Gjøvik, Sykehuset Innlandet, og forsker ved Senter for rus- og avhengighetsforskning. Universitetet i Oslo.

Forfatter har fylt ut ICMJE-skjemaet og oppgir ingen interessekonflikter.

\section{Thomas Clausen (f. 1972)}

er professor ved Senter for rus- og avhengighetsforskning; Universitetet i Oslo.

Forfatter har fylt ut ICMJE-skjemaet og oppgir ingen interessekonflikter.

\section{Anne Bukten (f. 1977)}

er postdoktor ved Senter for rus- og avhengighetsforskning ved Universitetet i Oslo.

Forfatter har fylt ut ICMJE-skjemaet og oppgir ingen interessekonflikter.

\section{Litteratur}

1. Degenhardt L, Bucello C, Mathers B et al. Mortality among regular or dependent users of heroin and other opioids: a systematic review and meta-analysis of cohort studies. Addiction 2011; 106: 32-51.

2. Caplehorn JR, Dalton MS, Haldar F et al. Methadone maintenance and addicts' risk of fatal heroin overdose. Subst Use Misuse 1996; 31: 177-96.

3. Clausen T, Anchersen K, Waal H. Mortality prior to, during and after opioid maintenance treatment (OMT): a national prospective cross-registry study. Drug Alcohol Depend 2008: 94: 151-7.

4. Clausen T, Waal H, Thoresen M et al. Mortality among opiate users: opioid maintenance therapy, age and causes of death. Addiction 2009; 104: $1356-62$.

5. Gossop M, Trakada K, Stewart D et al. Reductions in criminal convictions after addiction treatment: 5-year follow-up. Drug Alcohol Depend 2005; 79: 295-302.

6. Darke S, Ross J, Teesson M. The Australian Treatment Outcome Study (ATOS): what have we learnt about treatment for heroin dependence? Drug Alcohol Rev 2007; 26: 49-54.

7. Bukten A, Skurtveit S, Stangeland P et al. Criminal convictions among dependent heroin users during a 3-year period prior to opioid maintenance treatment: a longitudinal national cohort study. J Subst Abuse Treat 2011; 41: 407-14.

8. Havnes I, Bukten A, Gossop M et al. Reductions in convictions for violent crime during opioid maintenance treatment: a longitudinal national cohort study. Drug Alcohol Depend 2012; 124: 307-10.

9. Bukten A, Herskedal A, Skurtveit S et al. Driving under the influence (DUI) among patients in opioid maintenance treatment (OMT): a registry-based national cohort study. Addiction 2013; 108: 1954-61.

10. Skeie I, Brekke M, Gossop M et al. Changes in somatic disease incidents during opioid maintenance treatment: results from a Norwegian cohort study. BMJ Open 2011; 1: e000130.

11. Waal H, Bussesund K, Clausen T et al. Statusrap port 2012 - LAR som det vil bli fremover? Oslo: Senter for rus- og avhengighetsforskning, Universitetet i Oslo, 2013

12. Olsen ST. forebygging.no. KoRus-Nord, 2013 www.forebygging.no/ (3.1.2014).

13. Gjersing L, Bretteville-Jensen AL. Is opioid substitution treatment beneficial if injecting behaviour continues? Drug Alcohol Depend 2013: 133: 121-6.

14. Skeie I, Brekke M, Clausen T et al. Increased somatic morbidity in the first year after leaving opioid maintenance treatment: results from a norwegian cohort study. Eur Addict Res 2013; 19: 194-201.

15. Magura S, Rosenblum A. Leaving methadone treatment: lessons learned, lessons forgotten, lessons ignored. Mt Sinai J Med 2001; 68: 62-74.

16. Hiltunen AJ, Eklund C, Borg S. The first 38 methadone maintenance treatment patients in Stock holm: 15-year follow-up with a main focus on detoxification from methadone. Nord J Psychiatry 2011; 65: 106-11.

17. Clausen T, Åsland $\mathrm{R}$, Kristensen $\emptyset$. Pasienter som avbryter LAR-behandling - hvordan går det med dem? Tidsskr Nor Legeforen 2014; 134: 1146-9.

18. Waal H, Gossop M. Making sense of differing overdose mortality: contributions to improved understanding of European patterns. Eur Addict Res 2014; 20: 8-15

19. Bernard JP, Havnes I, Slørdal L et al. Methadonerelated deaths in Norway. Forensic Sci Int 2013: 224: 111-6.

Mottatt 3.11. 2013, første revisjon innsendt 12.2 2014, godkjent 26.3. 2014. Redaktør: Are Brean. 